\title{
Information system for the content of natural and man-made radionuclides in building materials
}

\author{
Daria Buzina ${ }^{1, *}$ and Igor Engovatov ${ }^{1}$ \\ ${ }^{1}$ Moscow State University of Civil Engineering, 26, Yaroslavskoe shosse, 129337, Moscow, Russia
}

\begin{abstract}
Natural radionuclides include the $238 \mathrm{U}$ and $232 \mathrm{Th}$ radioactive families with daughter decay products and $40 \mathrm{~K}$ potassium. In addition to these, the raw materials may contain man-made radioactive nuclides formed due to accidents at the nuclear facilities and its uncontrolled release into the environment (for example, 137Cs). Reducing the impact of radiation exposure on humans and the environment is an urgent task, both in Russia and abroad, given the rapid quantitative growth of the range, manufacturers, suppliers and consumers of building materials associated with the general trend of urbanization. Currently, there is a large number of studies on the natural and man-made radioactivity of building materials. As a rule, they present disparate and local scientific results, which complicates their accessibility to a wide range of interested parties - manufacturers and consumers of construction products. Therefore, it is necessary that information on the radiation and environmental cleanliness of various materials and products was easily accessible to all comers. An information system on the natural and man-made radioactivity of building materials and products should become a tool for solving this problem. The work outlines the principles of creation and practical implementation, structure and content, goals, objectives of the field of destination and application of the information system for natural and man-made radioactivity of building materials and products.
\end{abstract}

\section{Introduction}

Natural and artificial sources of ionizing radiation determine the radiation impact on a person, both directly and through the environment, including the territory of residence, buildings and structures where we spend most of part the life.

The natural radioactivity of the building materials from which the buildings were erected is an essential component of human exposure and in some cases can lead to significant radiation doses. All construction materials, as well as raw materials for their production, contain one or another amount of natural radioactive nuclides (NRN). The most important of them is the radioactive family ${ }^{238} \mathrm{U}$ with daughter products of decay, the radioactive family ${ }^{232} \mathrm{Th}$ with daughter products of decay and potassium $-40\left({ }^{40} \mathrm{~K}\right)[1,2]$. Another source of radiation hazard may be man-made radioactive nuclides (MMRN) formed as a result of

* Corresponding autor: dn89@bk.ru 
various human activities in the field of scientific research, the nuclear industry, military and civil nuclear technologies, which can also be incorporated into building materials [5-8].

Almost all industrialized countries have the goal of reducing and limiting the radiation impact on the population through the natural radioactivity of building materials, including using standards, assessment criteria and application boundaries.

Quite tight control is exercised over the natural and man-made radioactivity in building materials and products from them in Russia. Certification system for building materials and raw materials for their manufacture has been formed, radiation monitoring laboratories are in operation according to Normy radiatsionnoy bezopasnosti (NRB-99/2009) and the Law of the Russian Federation № 3-FZ «Radiation Safety of the Population».. The regulatory documents stipulate measures for radiation inspection of the construction area, buildings and structures, as well as radiation monitoring of materials and products for these purposes. Numerous experimental studies of natural and man-made radioactivity have allowed us to accumulate valuable factual material on this issue. In some radiation monitoring laboratories, attempts have been made to form databases on the content of NRN in building materials, the most complete of which is available in the radiation control laboratory [5].

Nevertheless, the rapid quantitative growth of the nomenclature, manufacturers, suppliers and consumers of construction materials, including those imported from near and far abroad, the pace of housing construction in large cities make it difficult to comprehensively solve the problem of reducing radiation exposure on humans and their habitats. The creation of an ecologically safe and comfortable environment in places of residence and labor activity of a person is one of the important and priority tasks within the framework of the State program of the Russian Federation «Environmental protection» for 2012-2020.. At the same time, there is a situation where there is a large amount of information on this issue, there is a specific product and a specific consumer of this product, but there is no mechanism for their interaction and feedback. The consumer does not have sufficient qualifications and competence to influence the final result. In addition, the manufacturer does not have, and indeed should not, possess specific knowledge in the field of radiation safety and the sources of its occurrence throughout the entire production process chain.

In turn, the consumer must be sure of the safety of the materials from which residential and industrial facilities were built and be able to evaluate safety based on easy accessible and clearly stated information.

Current manufacturers are trying to reach a new level of quality of the product: now prestigious are materials with a high content of natural components, an important property of which is environmental cleanliness. Therefore, it is necessary to allow not only the consumer, but also the manufacturer to choose environmentally friendly raw materials.

A huge amount of research on the natural and man-made radioactivity of building materials has been and is currently being conducted, both in Russia and abroad [6-15]. All of them present disparate and local scientific results that can be found only after a sufficiently lengthy search in the Internet and libraries. Therefore, it is necessary that information on the environmental friendliness of various materials and products be easily accessible to all comers. The creation of a single information space has been repeatedly mentioned earlier [15].

In a broader sense, a transition from individual disparate studies to the creation of an information system on the natural and man-made radioactivity of building materials and products (ISNMMR) is necessary. 


\section{Methodological approaches to the construction of ISNMMR, structure and content}

The information system for natural and man-made radioactivity should include: a database on the NER in building materials and raw materials, regulatory documents, methods, tools and recommendations for creating a favorable climate in terms of the radiation factor, recommendations for the use of building materials and products for industrial and civil engineering.

In general, ISNMMR should include following blocks:

- regulations;

- experimental measurement techniques;

- database of natural radionuclides in rocks (raw materials);

- database of natural radionuclides in building materials;

- radiation background calculation programs in residential and industrial premises;

- methods and means of selecting material with a minimum content of NRN;

- recommended materials for industrial and civil engineering.

The block diagram is shown in figure 1 .

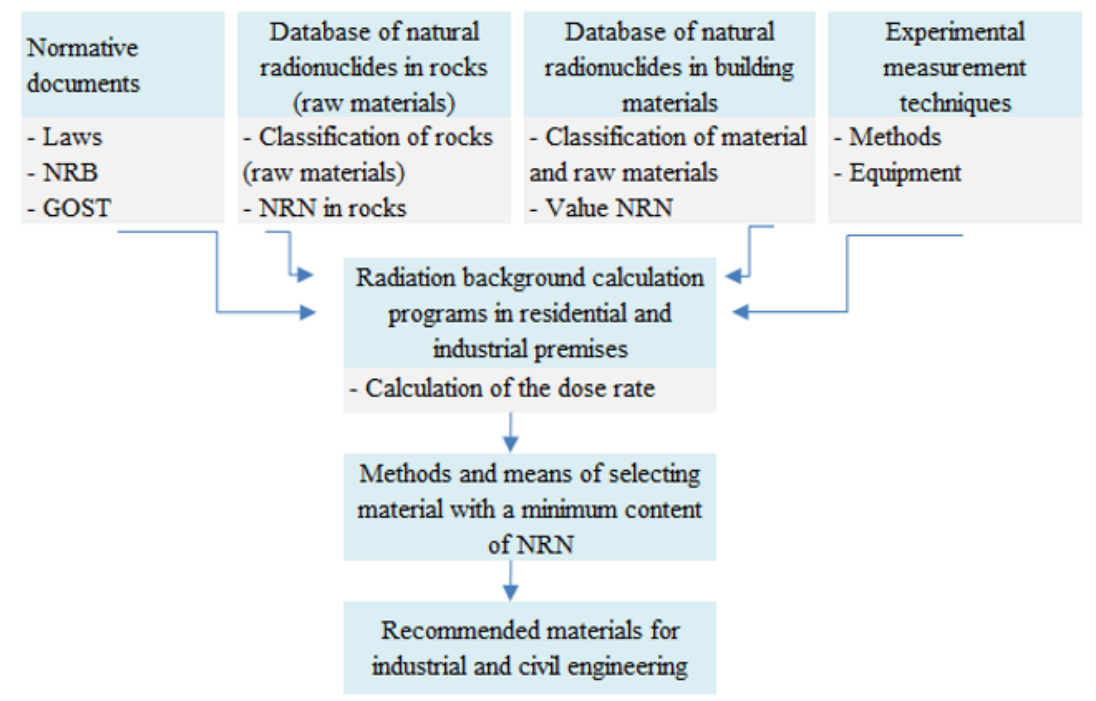

Fig. 1. The block diagram ISNMMR.

The «Regulatory documents» block contains the documents regulating the radiation safety of the population, in which the permissible doses of radiation, classes of building materials, their possible application, as well as methods for determining classes are prescribed. Such documents include laws, regulatory legal acts - NRB, GOST. In this block recommendations of international organizations regulating safety issues when using building materials are also placed in a user-friendly form.

The «Database on NRN in rocks (raw materials)» block contains theoretical, calculated and experimental information on the classification of rocks and their radiation hazard. The information in this block is fundamental for the development of new materials and a preliminary assessment of the radiation hazard of long-used materials.

The block «Databases on the content of NRN in building materials» is the most informative and constantly updated.

As example figures 2 and 3 show the databases on NRN in masonry material (brick) and finishing material (granite), respectively. 


\begin{tabular}{|c|c|c|c|c|c|c|c|c|c|}
\hline & & $11 \quad 1 \quad 2$ & $-1 \quad 3 \mid 1$ & $5 \quad 1 \quad 6$ & $\begin{array}{lll}1 & 7 & 1 \\
2 & 1\end{array}$ & $81 \quad 9$ & $1=101$ & $7|12|$ & $\begin{array}{lll}1 & 13 \\
\end{array}$ \\
\hline & 1 & 2 & 3 & 4 & 5 & 6 & 7 & 8 & 9 \\
\hline 1 & \multicolumn{9}{|c|}{ Content of natural radionuclides in masonry material } \\
\hline 2 & & & & & & & & & \\
\hline 3 & № & Material & Stamp & $\begin{array}{l}\text { Country of } \\
\text { origin }\end{array}$ & ${ }^{226} \mathrm{Ra}, \mathrm{Bq} / \mathrm{kg}$ & ${ }^{232} \mathrm{Th}, \mathrm{Bq} / \mathrm{kg}$ & ${ }^{40} \mathrm{~K}, \mathrm{~Bq} / \mathrm{kg}$ & Aeff, $\mathrm{Bq} / \mathrm{kg}$ & $\begin{array}{l}\text { Class of } \\
\text { materials }\end{array}$ \\
\hline 4 & 1 & brick & Vitebsk furnace M200 & Belarus & 28 & 34 & 577 & 124,0 & 1 \\
\hline 5 & 2 & brick & Roben CHELSEA M1000 & Germany & 24 & 22 & 304 & 79,9 & 1 \\
\hline 6 & 3 & brick & OOO "EKZ" & Russia & 29 & 34 & 461 & 114,7 & 1 \\
\hline 7 & 4 & brick & ZHKZ M200 & Russia & 37 & 30 & 367 & 107,9 & 1 \\
\hline 8 & 5 & brick & ZHKZ M150 & Russia & 37 & 32 & 392 & 114,1 & 1 \\
\hline-9 & 6 & brick & SZLK M150 & Russia & 17 & 20 & 432 & 81,9 & 1 \\
\hline 10 & 7 & brick & Terbunsky Potter M200 & Russia & 32 & 31 & 232 & 92,9 & 1 \\
\hline 11 & 8 & brick & Terbunsky Potter M200 & Russia & 19 & 22 & 247 & 70,2 & 1 \\
\hline 12 & 9 & brick & Vorotynsky M150 & Russia & 25 & 27 & 380 & 94,6 & 1 \\
\hline 13 & 10 & brick & Vorotynsky M175 & Russia & 28 & 26 & 329 & 92,2 & 1 \\
\hline-14 & 11 & brick & Kashirsky M200 & Russia & 25 & 26 & 399 & 95,3 & 1 \\
\hline 15 & 12 & brick & OOO "TKZ" M200 & Russia & 27 & 23 & 367 & 89,5 & 1 \\
\hline 16 & 13 & brick & LKZ M150 & Russia & 26 & 28 & 402 & 98,9 & 1 \\
\hline 17 & 14 & brick & Aleksinskij M150 & Russia & 25 & 33 & 446 & 107,6 & 1 \\
\hline-18 & 15 & brick & Lomincevo M150 & Russia & 28 & 33 & 427 & 109,4 & 1 \\
\hline 19 & 16 & brick & Bogorodskij M175 & Russia & 21 & 25 & 354 & 85,0 & 1 \\
\hline 20 & 17 & brick & Bogorodskij M150 & Russia & 23 & 25 & 369 & 87,9 & 1 \\
\hline 21 & 18 & brick & Losinoostrovskij M150 & Russia & 33 & 31 & 301 & 100,1 & 1 \\
\hline-22 & 19 & brick & GKZ M150 & Russia & 17 & 31 & 308 & 85,1 & 1 \\
\hline 23 & 20 & silicate brick & KZSK M200 & Russia & 4 & 2 & 51 & 11,5 & 1 \\
\hline
\end{tabular}

Fig. 2. Database on NRN in masonry material (brick).

\begin{tabular}{|c|c|c|c|c|c|c|c|c|c|c|}
\hline & & 1 & 2 & 3 & 4 & 5 & 6 & 7 & 8 & 9 \\
\hline - & 1 & & & & Content of nat & al radionucli & $s$ in granite & & & \\
\hline & 2 & & & & & & & & & \\
\hline & 3 & № & Material & Stamp & $\begin{array}{l}\text { Country of } \\
\text { origin }\end{array}$ & $\begin{array}{l}{ }^{226} \mathrm{Ra}, \\
\mathrm{Bg} / \mathrm{kg}\end{array}$ & $\begin{array}{l}{ }^{232} \mathrm{Th}, \\
\mathrm{Bg} / \mathrm{kg}\end{array}$ & ${ }^{40} \mathrm{~K}, \mathrm{~Bq} / \mathrm{kg}$ & $\begin{array}{l}\text { Aeff, } \\
\mathrm{Bq} / \mathrm{kg}\end{array}$ & $\begin{array}{l}\text { Class of } \\
\text { material }\end{array}$ \\
\hline & 4 & 1 & granite & Nero Zimbabwe & Africa & $14,6 \pm 0,5$ & $24,1 \pm 0,4$ & $264,6 \pm 13,7$ & $68,8 \pm 1,8$ & 1 \\
\hline & 5 & 2 & granite & Giallo Topazio & Brazil & $21,6 \pm 2,1$ & $53,3 \pm 2$ & $1434,4 \pm 67,7$ & $213,3 \pm 8$ & 1 \\
\hline 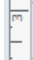 & 6 & 3 & granite & \begin{tabular}{|l} 
Japarano \\
Classico
\end{tabular} & Brazil & $47,5 \pm 0$ & $100,4 \pm 0$ & $1061,2 \pm 0$ & $269,3 \pm 0$ & 1 \\
\hline$=$ & 7 & 4 & granite & Verde Bahia & Brazil & $50,3 \pm 5,2$ & $60,1 \pm 5,8$ & $1032,6 \pm 22,8$ & $216,7 \pm 14,7$ & 1 \\
\hline 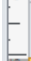 & 8 & 5 & granite & \begin{tabular}{|l|} 
Verde \\
Guatemala \\
\end{tabular} & Guatemala & $0,3 \pm 0,5$ & $0,3 \pm 0,4$ & $0,3 \pm 0,5$ & $0,7 \pm 0,7$ & 1 \\
\hline & 9 & 6 & granite & Kletka Kuser & Egypt & $13,5 \pm 0$ & $10,7 \pm 0$ & $400,1 \pm 0$ & $61,4 \pm 0$ & 1 \\
\hline 6 & 10 & 7 & granite & \begin{tabular}{|l|} 
Absolute Black \\
(Blacko.32)
\end{tabular} & India & $13,8 \pm 0,4$ & $15,5 \pm 0,7$ & $313,7 \pm 9,5$ & $60,7 \pm 0,4$ & 1 \\
\hline- & 11 & 8 & granite & Blue Laguna & India & $2,8 \pm 0,7$ & $3,5 \pm 0,9$ & $657,9 \pm 215,4$ & $63,4 \pm 20$ & 1 \\
\hline$E$ & 12 & 9 & granite & \begin{tabular}{|l|} 
Coral Silk \\
(Ivory Brown)
\end{tabular} & India & $16,3 \pm 0$ & $41,1 \pm 0$ & $1096,5 \pm 0$ & $162,9 \pm 0$ & 1 \\
\hline & 13 & 10 & granite & Crystal Red & India & $46,3 \pm 0,7$ & $178,1 \pm 13,8$ & $1520,3 \pm 9,9$ & $408,7 \pm 19,5$ & 2 \\
\hline- & 14 & 11 & granite & Forest Green & India & $16,6 \pm 0,6$ & $88,1 \pm 9,9$ & $1264,1 \pm 90,5$ & $239,5 \pm 20,2$ & 1 \\
\hline & 15 & 12 & granite & Imperial White & India & $114,5 \pm 3,1$ & $100,9 \pm 0,7$ & $1331,8 \pm 19,7$ & $359,9 \pm 2,2$ & 1 \\
\hline क & 16 & 13 & granite & Ivory Brown & India & $30,4 \pm 2,7$ & $7,7 \pm 1,3$ & $1086,9 \pm 11,2$ & $132,9 \pm 5,4$ & 1 \\
\hline- & 17 & 14 & granite & Kashmir White & India & $76,2 \pm 16,2$ & $43,2 \pm 16,5$ & $1309,8 \pm 90,4$ & $244,1 \pm 45,4$ & 1 \\
\hline ga & 18 & 15 & granite & Multicolor & India & $11,6 \pm 2,3$ & $41,1 \pm 20,4$ & $1246,4 \pm 61$ & $171,3 \pm 23,7$ & 1 \\
\hline F & 19 & 16 & granite & Paradiso & India & $1,9 \pm 0,3$ & $1,7 \pm 0,4$ & $748,3 \pm 22,1$ & $67,8 \pm 1,5$ & 1 \\
\hline$\Rightarrow$ & 20 & 17 & granite & Pine Green & India & $18,5 \pm 0,5$ & $47,8 \pm 3,6$ & $1771,1 \pm 30,8$ & $231,7 \pm 6,9$ & 1 \\
\hline$F$ & 21 & 18 & granite & $\begin{array}{l}\text { Raw Silk (Rosy } \\
\text { White) } \\
\end{array}$ & India & $226,6 \pm 81,4$ & $78,1 \pm 14,8$ & $1210,1 \pm 87,8$ & $431,8 \pm 98,4$ & 2 \\
\hline$\approx$ & 22 & 19 & granite & Red Multicolor & India & $7,6 \pm 0,8$ & $52,1 \pm 1,2$ & $1057,3 \pm 112,5$ & $165,7 \pm 10,4$ & 1 \\
\hline & 23 & 20 & granite & Tiger Skin & India & $40,5 \pm 13,1$ & $53,3 \pm 3,7$ & $1637,2 \pm 14,5$ & $249,5 \pm 9,5$ & 1 \\
\hline 可 & 24 & 21 & granite & Verde Marina & India & $52,8 \pm 3,8$ & $29,9 \pm 1,8$ & $848,8 \pm 54,9$ & $164,1 \pm 3,2$ & 1 \\
\hline & 25 & 22 & granite & Porto Rosa & Spain & $57,1 \pm 1,8$ & $82,6 \pm 10,1$ & $1483,5 \pm 80,5$ & $291,3 \pm 21,8$ & 1 \\
\hline$\Rightarrow$ & 26 & 23 & granite & Salvatiera & Spain & $115,8 \pm 4,8$ & $96,7 \pm 8,9$ & $1333,3 \pm 96,8$ & $355,8 \pm 14,6$ & 1 \\
\hline$E$ & 27 & 24 & granite & White Grev & Spain & $120 \pm 0$ & $44.1 \pm 0$ & $1464.2 \pm 0$ & $301.8 \pm 0$ & 1 \\
\hline
\end{tabular}

Fig. 3. Database on NRN in granite. 
The presented databases, which are functional blocks in the general ISNMMR, provide the necessary information about the types of materials, their manufacturers, effective radioactivity and class of material from the point of view of application for various fields of construction.

The block «Experimental measurement techniques» contains the methods for measuring the functionals of radiation fields, a list and characteristics of the used spectrometric and radiometric equipment.

The block «Programs and methods for calculating the radiation situation in residential and industrial premises» contains engineering programs and techniques that allow calculating or evaluating dose rates from arrays of building materials and raw materials, dose rates in a room at a height of $1 \mathrm{~m}$ above the floor. Programs take into account the geometry of residential and industrial premises, the composition of walling and finishing materials, i.e. all used building materials and the thickness of each layer are indicated in layers.

The block «Methods and means of selecting a material with a minimum content of NRN» is intended for the implementation of two main options: reducing the quantitative use of radiation hazardous building material and raw materials if it is impossible to replace it with another, as well as the use of material with a minimum content of NRN.

The block «Recommended materials for industrial and civil construction» contains a list of the safest materials from the point of view of radiation safety, depending on the application.

\section{Analysis and summery}

The information system will provide an opportunity to solve many problems, the most important of which are:

- providing information on the main materials used in construction, understandable and convenient for any user, with the help of which he will be able to determine in each specific case the necessary set of materials that will be optimal from the point of view of radiation and environmental indicators;

- targeted selection of «radioactive-clean» materials;

- creation by manufacturers of «radioactive-clean» materials from the investigated raw materials;

- design of buildings and structures taking into account the radiation and environmental factor;

- the user, having the opportunity to turn to ISNMMR, will be able to assess the radiation situation at different stages of design, choosing subsequently environmentally friendly materials and products, if this is not possible, then materials with a minimum content of these substances;

- when implementing, ISNMMR it is necessary to strive for maximum simplification for the user, for example, by using the concept of Windows.

Such data completeness are ensured by the application of the proposed geoecological assessment of the radiation hazard of the use of rocks in the building materials industry [15].

A manufacturer of building materials can become a user of an information system by choosing the least radioactive raw materials, a designer and a builder, choosing the least radioactive building materials, and a consumer who is interested in the radiation background of his home.

Information system users are listed in figure 4. 


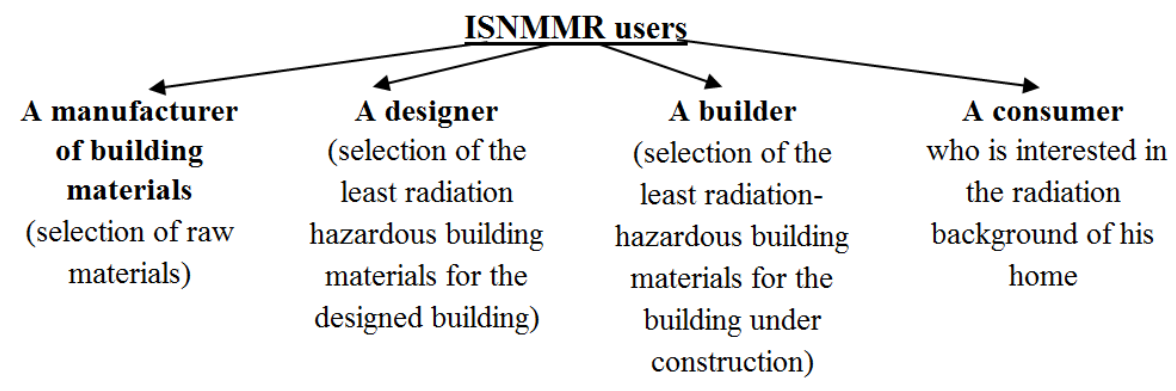

Fig. 4. ISNMMR users.

\section{Conclusion}

1. The developed structure of the information system for the content of NRN and MMRN in building materials, rocks and raw materials for their production will make it possible to solve many problems, the main of which are:

- targeted selection of «radioactive-clean» materials;

- creation by manufacturers of «radioactive-clean» materials from the investigated raw materials;

- design of buildings and structures taking into account the radiation and environmental factor.

2. This information system is designed to become a tool in the production of new materials with a minimum content of natural radionuclides and to exclude the use of «radiationhazardous» materials using waste.

3. ISNMMR will allow the consumer to monitor the radiation characteristics of materials used in individual construction by himself.

\section{References}

1. IAEA Safety Standards. General Safety Requirements Part 3 (IAEA,Venna, 2015)

2. European Commission. Radiation protection 112 Radiological Protection Principles concerning the Natural Radioactivity of Building Materials (Directorate-General Environment, Nuclear Safety and Civil Protection, EC Luxemburg, 1999)

3. Evaluation of EPA's Guidelines for TENORM (U.S. EPA, 2000)

4. NUREG-1501 (U.S. Nuclear Regulatory Commission Office of Nuclear Regulatory Research Washington, 1994)

5. Radiation control laboratories LRK-1 MIFI, http://www.radiation.ru/Base/bd.htm

6. S. Fare, A.M. Yassene Ali, A. Ashour, M.K. Abu-Assy, M. El-Rahman, Nat. Sci. 3(10), 895-905 (2011) DOI:10.4236/ns.2011.310115

7. D.V. Buzina, I.A. Engovatov, D.D. Nguyen, A. Ovakivean, MATEC Web of Conf. 196, 04064 (2018) https://doi.org/10.1051/matecconf/201819604064

8. M.M. Uosif, Int. J. of u- and e- Service, Sci. and Technol. 7(2), 63-76 (2014) http://dx.doi.org/10.14257/ijunesst.2014.7.2.06

9. Y. Raghu, N. Harikrishnan, A. Chandrasekaran, R. Ravisankar, African J. of Basic \& Applied Sci. 7(1), 16-25 (2015) DOI: 10.5829/idosi.ajbas.2015.7.1.1140

10. M. Rafique, Iranian journal of radiation research 9(2), 77-87 (2011) https://studylib.net/doc/18826807/assessment-of-radiological-hazards-due-to-soil-and- 
building

11. W.R. Alharbi, J.H. AlZahrani, J. of American Sci. 8(10), 651-656 (2012)

12. D.V. Buzina, I.A. Engovatov, L.A. Alimov, M.Y. Slesarev, MATEC Web of Conf. 86, 04044 (2016) DOI: 10.1051/matecconf/20168604044

13. D.V. Buzina, I.A. Engovatov, IOP Conf. Ser.: Mater. Sci. Eng. 365, 042029 (2018) doi:10.1088/1757-899X/365/4/042029

14. D.V. Buzina, I.A. Engovatov, E3S Web Conf. 97, XXII Int. Sci. Conf. Construction the $\begin{array}{llll}\text { Formation of } & \text { Living } & \text { Environment } \\ \text { https://doi.org/10.1051/e3sconf/20199703020 }\end{array}$ 